ISSN: 2146-3042

DOI: $10.25095 /$ mufad.947821

\title{
Türkiye’de Finansal Sistemden Sağlanan Çeşitli Getirilerin VAR Modeli İle Etkileşimlerinin Analizi*
}

\author{
Kudbeddin ŞEKER**
}

\section{ÖZET}

Araştırmada Türkiye'de finansal sistem içinde yer alan finansal araçların getirileri olarak değerlendirilen BIST 100 endeksi, faiz, euro, dolar, altın ve devlet iç borçlanma senedi (DIBS) arasındaki etkileşimler 2005M1-2021M1 dönemlerine ait TÜFE bazlı aylı reel getiri oranları kullanılarak VAR analizi ile incelenmiştir. Araştırmanın veri setinde tüm bu değişkenlerin bir arada yer alması çalışmayı önemli kılmaktadır. Araştırmada etki-tepki analizinden elde edilen sonuçlara göre, tüm getiri değişkenlerinin kendilerinde oluşan şoklara ilk dönemde hep pozitif tepki verdikleri görülmüşürr. Türkiye' de finansal sistemden sağlanan getiri araçlarından, BIST 100 endeks getirisi ile faiz, altın, dolar ve DIBS getirileri arasında hem tamamlayıcılık ve hem de ikame ilişkisi bulunmuştur. Devlet İç Borçlanma Senedi (DIBS), faiz ve dolar getirilerinin daha çok birbirleriyle etkileşim içinde oldukları tespit edilmiştir. Bu değişkenler arasındaki ilişkinin finansal araçlardan sağlanan getirilerin sınanması nedeniyle analiz sonuçlarının yatırımcılara, ekonomik birimlere ve literatüre katkı sağlayacă̆ı düşünülmektedir.

Anahtar Kelimeler: Finansal Araçların Getirileri, Varyans Ayrıştırması, Etki-Tepki Fonksiyonu, Vektör Otoregresif (VAR) Modeli

JEL Sınıflandırması: O16, G11, C58

Analysis of The Interactions of Various Returns Provided from the Financial System Through VAR Model in Turkey

\section{ABSTRACT}

In the study, the relationships between the BIST 100 index, interest, euro, dollar, gold and government debt securities (GDS) returns, which are among the financial investment instruments in the Turkish financial system, are analyzed. The interaction of these variables with each other VAR analysis based on the period of 2005M1-2021M1 and CPI-based real return rates are analyzed. The fact that all these variables are included in the data set of the research makes the study important. According to the results obtained from the impulseresponse analysis in the study, it was observed that all return variables always respond positively to a standard deviation shock occurring in them in the first period. There is both a complementary and a substitute relationship between the returns of various investment instruments such as the BIST 100 index, interest, gold, dollar and GDS, which are tools for generating returns. GDS, interest and dollar returns have been found to interact more with each other. It is thought that the results of the analysis will contribute to investors, economic units and the literature, since the relationship between these variables is tested on the returns from financial instruments.

Keywords: Income of Financial Instruments, Variance Decomposition, Impulse-Response Function, Vector Autoregression (VAR) Model

Jel Classification: O16, G11, C58

\footnotetext{
* Makale Gönderim Tarihi: 04.06.2021, Makale Kabul Tarihi: 19.08.2021, Makale Türü: Nicel Araştırma

** Dr. Öğr. Üyesi, Kütahya Dumlupınar Üniversitesi, Kütahya Uygulamalı Bilimler Fakültesi kudbeddin.seker@dpu.edu.tr, ORCID: 0000-0001-6705-2890.
} 


\section{GİRIŞ}

Yaşanan ekonomik gelişmelerle birlikte finansal sistem içinde, finansal araçlar ve bunlardan elde edilen getiriler önem arz etmektedir. Finansal piyasalarda teknolojinin gelişmesi sayesinde finansal araçlar ile ilgili bilgi akışı hızlanmakta, aynı zamanda bilginin maliyeti azalmaktadır. Bu da finansal araçlardan elde ettikleri getirilerini maksimize etmek isteyen yatırımcılara çok çeşitli alternatifler sunmaktadır. Yatırımcılar piyasalardaki oynaklık ve riskler karşısında temkinli davranmaktadırlar. Finansal araçların getiri için satın alınması, satılması ve ya elde tutulması için geliştirilecek stratejilerin belirlenmesinde, finansal araçların birbirleriyle etkileşimlerinin, ikame ve tamamlayıcılık ilişkilerinin iyi bir şekilde analiz edilmesi gerekmektedir.

Ülkemizde serbest ticaretin gelişmesiyle birlikte 1985 y1lından itibaren finansal piyasaların büyük bir kısmı kurulmuştur. Sermaye Piyasası Kanunu (1981) ve Türk parasının konvertible hale gelmesi (1991) ile uygulanan liberal uygulamalar sonucunda finansal piyasalar bugün ülke ekonomisinde önemli bir yere sahip olmuştur (Karan, 2018:3-20). Ayrıca 28.07.1981 tarihli ve 2499 sayılı Sermaye Piyasası Kanunu'nu yürürlükten kaldıran, 06.12.2012 tarihli ve 6362 sayılı Sermaye Piyasas1 Kanunu'nun 30.12.2012 tarihli Resmi Gazete'de yayımlanarak yürürlüğe girmesi ile mevzuatımızın da günün koşullarına göre revizyonu mümkün olmuştur.

Finansal getiri araçlarında düşük risk ve yüksek getiri sağlanması finansal sistemin gelişmesini sağlamaktadır. Finansal araçların daha likit hale gelmesi, borç ödemelerini kolaylaştırmaktadır. Aynı zamanda finansal riskler tabana dağıtılarak risk transferi gerçekleştirilebilmektedir. Finansal piyasaların gelişmişliği finansal sistemde kullanılan finansal araçların yaygınlaşması ve çeşitlendirilmesi ile sağlanmaktadır (Öz vd., 2020:161). Finansal piyasalarda getiri elde etme için yapılan işlemlerde sahip olunan finansal varlıkların değerlendirilme sürecinde, en az riski alacak şekilde en fazla getiriyi sağlayacak finansal araçlara paylaştırılması gerektiği Markowitz (1952) tarafından geliştirilen "Portföy Teorisi” ile açıklanmıştır. Modern Portföy Kuramı yatırımcıların rasyonel davranıp, daha fazla getiri isterken devamlı riskten kaçındıkları böylece beklenen getirileri artarken riskten kaçındıklarını varsaymıştır. Maksimum getiriye karşılık minimum risk istenmektedir (Karan, 2018:139). Bireysel olarak yatırım yapılan menkul kıymetlerin birbirleri olan ilişkileri konusunda Markowitz, yatırımcıların mevcut portföylerine menkul kıymetlerin seçimi sırasında geçmiş performansların yanı sıra menkul kıymetlerin birbirleri ile olan karşılıklı etkileşimlerinin de incelenmesi gereğini belirtmektedir (Yiğiter ve Akkaynak, 2017:288).

Yapılan çalışmalarda, menkul kıymetlerin birbirlerini negatif yönde etkiledikleri görülmektedir. Joseph (2002), hisse senetleri getirisi, faiz oranı ve döviz kuru arasında negatif yönlü bir ilişki olduğunu, Hatemi ve Irandoust (2002), hisse senedi fiyatı ve döviz kuru arasında negatif yönlü bir ilişki olduğunu ifade etmişlerdir. Yıldız (2014), altın fiyatları, döviz kuru ve faiz oranları ile BIST 100 pay endeks ilişkisinde negatif yönlü ilişki olduğunu belirtmiştir. Gunasekarage vd. (2004), faiz oranı, enflasyon ve para arzının borsayı etkilediğini, Çiçek (2010), Devlet İç Borçlanma Senedi (DIBS), döviz kuru ve hisse senedi piyasasında oynaklıktan kaynaklı şokların etkili, oynaklık yayılım etkisinin döviz ve hisse senedi piyasası ile DIBS ve hisse senedi piyasası arasında karşılıklı olduğunu ifade etmiştir. Doğru ve Recepoğlu (2014), hisse senetlerinin fiyat endeksi ile Dolar/TL ve Euro/TL ilişkisinde, pozitif ve negatif bir ilişki ile ilişki yönünün döviz kurundan hisse senedine doğru 
olduğunu belirtmiştir. Aytekin ve Dube (2016), DIBS gösterge faizi, BIST 30 endeksi, dolar kuru, euro kuru ve altın ilişsisinde kısa süreli etkileşimlerin olduğunu, Cingöz ve Kendirli (2019), BIST 100 Hisse Senedi Endeksi ve dolar döviz kurundaki değişimlerin altın fiyatlarına uzun dönemde etki ettiğini belirtmişlerdir.

Araştırmada kullanılan değişkenlerden euro getirisi, dolar getirisi ile BIST 100 endeks getirisi arasındaki ilişki geleneksel yaklaşım ve portföy teorisi ile açıklanabilmektedir. Geleneksel yaklaşıma göre euro ve dolar kurlarındaki artış BIST 100 endeksini artırmaktadır. Portföy yaklaşımına göre ise BIST 100 endeks getirisindeki artışlar euro ve dolar kurlarında düşüşe neden olmaktadır. Faiz oranlarında ortaya çıkacak artış iskonto oranlarını yükselterek maliyet artışı nedeniyle üretimde düşüşe yol açacaktır. Bu durumda yatırımcılar devlet iç borçlanma senedi (DIBS) gibi sabit getirili menkul kıymetlere yönelecek ve BIST 100 endeks getirisi ile negatif bir ilişki içinde olacaktır (Saka Ilgın ve Sarı, 2020:486). Araştırmada kullanılan altın getirisi değişkeni ile euro getirisi, dolar getirisi, faiz getirisi ve BİST 100 endeks getiri değişkenleri arasında uzun dönemli bir ilişki bulunmamaktadır. Altın getirisi ile BİST 100 endeksi arasında negatif bir ilişki, euro getirisi, dolar getirisi ve faiz getirisi arasında pozitif bir ilişki açıklanmıştır (Elmastaş Gültekin ve Aktürk Hayat, 2016:622).

$\mathrm{Bu}$ araştırmada finansal sistemden sağlanan çeşitli getirilerin birbirleriyle olan etkileşimi ele alınmıştır. İncelenen değişkenlerin kendilerine uygulanan şoklara karşı nasıl tepki verdikleri, birbirlerinden nasıl etkilendikleri araştırılmıştır. Araştırma güncel bir konuyu ele alarak, BIST 100 endeks getirisi, faiz getirisi, euro getirisi, dolar getirisi, altın getirisine ilaveten DIBS getirisini de içermektedir. Veri setinde tüm bu değişkenlerin bir arada yer alması ile birlikte, bu değişkenler arasındaki ilişkinin finansal araçlardan sağlanan getirilerin sınanması nedeniyle analiz sonuçlarının yatırımcılara, ekonomik birimlere ve literatüre katkı sağlayacağı düşünülmektedir. Finansal piyasalarda işlem gören TÜFE bazlı finansal getirileri ölçülebilen BIST 100 endeksi, faiz, euro, dolar, altın ve DIBS finansal getiri araçlarının 2005M1-2021M1 dönemi baz alınarak birbirleriyle etkileşimlerinin Vektör Otoregresif (VAR) modeli ile analizi araştırmamızın amacını oluşturmaktadır.

\section{LITERATÜR TARAMASI}

Çalışmamızda finansal araçlardan elden edilen getiriler kapsamında incelenen finansal değişkenler (BIST 100 endeksi, faiz, altın, dolar, euro, DIBS) ile ilgili literatürde, bu değişkenlerin kendi aralarında olan etkileşimleri ve bu değişkenler baz alınarak başka değişkenler üzerindeki etkileri ile ilgili çeşitli araştırmalar yapılmıştır. Bu çalışmalar incelenen değişkenlerin türleri (her çalışmada kullanılan değişken sayısı), ele alınan inceleme dönemleri, dönemlerin zaman serisi içinde incelenen periyodik zaman dönemleri (gün, hafta, ay, yıl vb.), verilerin elde edilme ve kullanılma şekillerine göre değişiklik göstermektedir.

Saka Ilgın ve Sarı (2020), uzun dönemde döviz kurundaki artış ile kısa ve uzun dönemde faiz oranlarındaki artış hisse senedi endekslerini düşürdüğünü belirtmişlerdir. Barut vd. (2017), faiz oranındaki artışların BIST 100 Ulusal Endeksi'ni negatif etkilediğini, döviz kurlarındaki artışın ise BIST 100 Ulusal Endeksi'ni pozitif yönde etkilediğini öne sürmüştür. Aktaş vd.(2018), dolar kurunda meydana gelen şokların BIST100 endeks getirisini azalttığı sonucuna ulaşmışlardır. Güler ve Özçalık (2018), Borsa Endeksi’nin dolar kurundan etkilendiğini, dolar kurunun da özellikle dolar endeksinden etkilendiğini tespit etmişlerdir. 
Makroekonomik değişkenlerin başka bir değişkenle ilişkilendirmeyerek kendi aralarındaki etkileşimleri (Cihangir vd., 2020 ve Topcu vd., 2013) tarafından analiz edilmiştir.

Finans ve ekonomi literatüründe makroekonomik faktörlerin, BIST 100 endeks getirileri, tüketim istihdam, altın fiyatları, vergi, turizm, ham petrol fiyatları vb. değişskenler arasındaki ilişkileri inceleyen birçok çalışma yer almaktadır. İlgili değişkenler ile makroekonomik verilerin etkilerinin incelendiği çalışmaların sonuçları, incelenen ülkelere ve dönemlere göre değişebilmektedir. Farklı zamanlarda ve değişik analiz modelleriyle yapılan çalışmalara aşağıda değinilmiştir.

Joseph (2002) yapmış olduğu çalışmasında, Granger (1969) nedensellik analizi ile1988-2000 döneminde İngiltere'de hisse senetleri getirisi, faiz oranı ve döviz kuru ilişkisini incelemiş, negatif yönlü bir ilişki tespit etmiştir.

Hatemi ve Irandoust (2002) yapmış oldukları çalışmalarında, VAR analizi ile 19931998 yılları İsveç Menkul Kıymetler Piyasası'nın hisse senedi fiyatı ve döviz kuru ilişkisi araştırılmış, araştırma sonucunda değişkenler arasında negatif yönlü bir ilişski tespit etmişlerdir.

Gunasekarage vd. (2004) yapmış oldukları çalışmalarında, vektör hata düzeltme modeli (VECM) ile aylık veriler kullanılarak Sri Lanka'daki makroekonomik değişkenlerin Kolombo borsası endeks ilişkisini para arzı, döviz kuru, enflasyon ve faiz oranı değişkenleri kullanarak analiz etmişlerdir. Analiz sonucunda faiz oranı, enflasyon ve para arzının borsayı etkilediği görülmüştür.

Çiçek (2010) yapmış olduğu çalışmasında, üssel genelleştirilmiş otoregresif koşullu değişen varyans (EGARCH) modelini kullanarak Türkiye'de 2004-2008 y1llarında DIBS, döviz kuru ve hisse senedi piyasası ilişkisini analiz etmiştir. Çalışma sonucunda oynaklıktan kaynaklı şokların etkili olduğu, oynaklık yayılım etkisinin döviz ve hisse senedi piyasası ile DIBS ve hisse senedi piyasası arasında karşılıklı olduğu belirtilmiştir.

Tangjitporm (2012) yapmış olduğu çalışmasında, VAR modeli ve Granger nedensellik testini kullanarak 2001-2010 dönemi aylık veriler ile Tayland'daki borsa endeksi ile işsizlik ve faiz oranı, enflasyon ve döviz kuru ilişkilerini analiz etmiştir. Analiz sonucunda makroekonomik değişkenlerin gelecekteki hisse senedi getirisinin tahmininde az önemli olduğu, ancak hisse senedi getirisinin makroekonomik değişkenlerin tahmininde kullanılabileceği tespit edilmiştir.

Topcu vd. (2013) yapmış oldukları çalışmalarında, Regresyon analizi, VAR modeli ve Vektör Hata Düzeltme Modeli (VECM) ile 2003-2011 aylık verileri baz alınarak altın ile hisse senedi, DIBS, ÜFE ve TÜFE ilişkisi araştırılmıştır. Araştırmada hisse senedi getirilerinde negatif, enflasyonla pozitif ilişki görülmüştür.

Doğru ve Recepoğlu (2014) yapmış oldukları çalışmalarında, Eşbütünleşme, Sınır ve Rank testini kullanarak, Türkiye'de 1980-2012 dönem aylık veriler ile hisse senetlerinin fiyat endeksi ile Dolar/TL ve Euro/TL ilişkisini analiz etmişlerdir. Analiz sonucunda pozitif ve negatif bir ilişki ile ilişsi yönünün döviz kurundan hisse senedine doğru olduğu tespit edilmiştir. 
Yıldız (2014) yapmış olduğu çalışmasında, VAR modeli ile 2001:03-2013:06 aylık verileri kullanarak altın fiyatları, döviz kuru ve faiz oranları ile BIST 100 pay endeks ilişkisini analiz etmiştir. Analiz sonucunda değişkenler arasında negatif yönlü ilişki bulunmuş, yatırımcıların portföy tercihinde bu değişkenleri kısa dönemde kullanabileceklerini ifade edilmiştir.

Sui ve Sun (2016) yapmış oldukları çalışmalarında, VAR modeli, VECM, gecikmesi dağıtılmış otoregresif (ARDL) ve Chow testleri ile döviz kurları, hisse senedi getirileri, faiz oranları ile ABD S\&P 500 getiri ilişkisi araştırılmıştır. Araştırmada döviz kuru şokları ve hisse senedi getirileri arasında önemli yayılma etkileri olduğu, bu etki sonucunda döviz kuru oynaklığının bir firmanın veya endüstrinin performansını etkileyebileceği belirtilmiştir. Ayrıca ABD S\&P 500 şoklarının Brezilya, Çin ve Güney Afrika'daki borsaları önemli ölçüde etkilediği ifade edilmiştir.

Aytekin ve Dube (2016) yapmış oldukları çalışmalarında, VAR ve Wald testlerini içeren Granger nedensellik analizi ile 2007-2012 dönemi günlük verilerle kuponsuz DIBS gösterge faizi, BIST 30 endeksi, dolar kuru, euro kuru ve altın ilişkisi analiz edilmiştir. Analiz sonucunda kısa süreli etkileşimlerin varlığ 1 belirtilmiştir.

Güler ve Özçalık (2018) yapmış oldukları çalışmalarında, 2016-2018 dönemi günlük veriler ile BIST 100 endeks, dolar endeks, Dolar/TL kuru endeks ve TCMB ortalama faiz oranları ilişkisi VAR ve Granger nedensellik analizi ile incelemiş ve tüm değişkenlerin birbirlerini etkilediğini tespit etmişlerdir.

Cingöz ve Kendirli (2019) yapmış oldukları çalışmalarında, altının fiyat hareketlerinde BIST 100 Hisse Senedi Endeksi ve dolar döviz kurundaki değişimlere olan etkisini Johansen Eşbütünleşme Testi ve Granger Nedensellik testi ile incelemişlerdir. BIST 100 Hisse Senedi Endeksi ve dolar döviz kurundaki değişimlerin altın fiyatlarına kısa dönemde etki etmediği, uzun dönemde ise etki ettiği sonucuna ulaşmışlardır.

Yıldırım vd. (2020) yapmış oldukları çalışmalarında, BIST mali getirileri ile enflasyon ve faiz oranları arasındaki ilişkiyi VAR analizi, Granger nedensellik testi, Etki- Tepki ve Varyans Ayrıştırması ile incelemişlerdir. Elde edilen sonuçlardan hisse senedi endeksinden enflasyona ve faizden BIST Mali Endeksi'ne doğru tek yönlü doğru Granger nedensellik ilişkisi olduğunu tespit etmişlerdir.

Yaghi (2020) yapmış olduğu çalışmasında, VAR modeli ile 2011-2017 aylık veriler ile Şam Menkul Kıymetler Borsası'nda endeksin fiyatları ile enflasyon oranı arasındaki nedensellik ilişkisini araştırmıştır. Araştırmada hisse senedi endeksinden enflasyona tek taraflı Granger nedensellik belirlenmiştir.

Demirkale ve Ebghaei (2020) yapmış oldukları çalışmalarında, BIST 100, BIST Kimya, BIST Sanayi, Dolar/TL, faiz oranı ile petrol fiyatlarının duyarlılık analizlerini VAR analizini kullanarak incelemiştir. Çalışma sonucunda BIST 100 endeksinden diğer değişkenlere doğru Granger nedensellik olduğu görülmüştür. 


\section{VERI}

Araştırmada Ocak 2005 - Ocak 2021 dönemleri için Türkiye’de finansal sistem içinde yer alan finansal araçların getirileri olarak değerlendirilen BIST 100 endeksi, faiz, euro, dolar, altın ve DIBS arasındaki ilişkiler incelenmiştir. Söz konusu değişskenlere ilişskin veriler aylara göre hesaplanmış dönemsel TÜFE bazlı reel getiri oranları olarak Türkiye İstatistik Kurumu veri tabanından elde edilmiştir. Araştırmada kullanılan seriler arasındaki ölçüm farklarını en az düzeye indirebilmek için serilerin doğal logaritması alınmıştır.

Modelde kullanılan getiri araçlarının hangi kaynaklardan alındığı, türü ve getiri araçlarının modelde kullanıldıkları ifadeler Tablo 1'de düzenlenmiştir. Tüm veriler, veri kaynağından TÜFE bazlı hesaplanmış olarak alınmıştır.

Tablo 1. Değişkenlere Ait Bilgiler (2005M1-2021M1)

\begin{tabular}{|llll|}
\hline Değişkenler & \multicolumn{1}{c}{ Tanımı } & Türü & Kaynak \\
\hline lnbist 100 & BIST 100 Endeks Getirisi & Makroekonomik Değişken & http://www.tuik.gov.tr \\
lnfaiz & Mevduat Faizi Getirisi & Makroekonomik Değişken & http://www.tuik.gov.tr \\
lneuro & Euro Getirisi & Makroekonomik Değişken & http://www.tuik.gov.tr \\
lndolar & Dolar Getirisi & Makroekonomik Değişken & http://www.tuik.gov.tr \\
lnaltin & Altın Getirisi & Makroekonomik Değişken & http://www.tuik.gov.tr \\
lndibs & Devlet İç Borçlanma Senetleri Getirisi & Makroekonomik Değişken & http://www.tuik.gov.tr \\
\hline
\end{tabular}

\section{YÖNTEM}

Araştırmada zaman serilerinin durağanlıkları Dickey ve Fuller'in (1979, 1981) geliştirmiş oldukları ADF ile Phillips ve Perron'un (1988) geliştirmiş oldukları PP birim kök testleri ile analiz edilmiştir. Analiz edilen değişkenler arasındaki eşanlı etkileşim VAR modeli ve bu modeli esas alan Etki-Tepki Fonksiyonları ile Varyans Ayrıştırması Analizi yöntemleriyle incelenmiştir.

\subsection{VAR Modeli}

Karmaşık modellerde, tüm modellerin birbirlerini etkileme derecesini, herhangi tek bir değişkene bağlı kalmayıp, tüm değişkenlerin modelde bütün olarak yer alması Vektör Otoregresif (VAR) modeli ile analiz edilebilir. VAR modeli Sims (1980) tarafından geliştirilmiştir.

VAR modelinin, dinamik ilişkilerde modele kısıtlama getirmemesi, bağımlı değişkenin VAR analiz modelinde önceki dönemlerine bağlı olarak gecikmeli değerlerinin kullanılması, ekonomik kriz dönemlerinde geçerli sonuçlar vermesi ve geleceğe yönelik güçlü tahminlerde bulunması zaman serilerinde sıklıkla kullanılmasını sağlamaktadır. VAR modeli, modelde bulunan değişkenlerde zaman süresince oluşacak şokların, diğer değişkenlerde ve gecikmeli değerlerinde yol açacak etkiyi ölçmektedir. 
VAR modelinin gecikmeli değerlere sahip olması geleceğe dair güçlü tahminlerde bulunmayı sağlamaktadır.

İki değişkenden oluşan basit VAR modeli aşağıdaki gibi ifade edilir:

$$
\begin{aligned}
& Y_{t}=\beta_{10}+\sum_{i=1}^{p} \beta_{11 i} Y_{t-i}+\sum_{i=1}^{p} \beta_{12} X_{t-i}+u_{1 t} \\
& X_{t}=\beta_{20}+\sum_{i=1}^{p} \beta_{21 i} Y_{t-i}+\sum_{i=1}^{p} \beta_{22} X_{t-i}+u_{2 t}
\end{aligned}
$$

Yukarıdaki modelde $\beta_{10}$ ve $\beta_{20}$ sabit terimi belirtirken, $p$ gecikme uzunluğunu, $u_{1 t}$ ve $u_{2 t}$ hata terimini belirtmektedir. $Y_{t}$ ve $X_{t}$ serileri durağan olmalıdır (Koyuncu ve Meçik, 2020:118).

VAR modelinin tahmininden sonra, tahmin edilen modelin durağan olmas1 gerekmektedir. Modelin tahmininden sonra hata terimlerinin test edilmesi sonucunda katsay1 matris özdeğerlerinin tümü birim çember içindeyse, modelin istikrarlı ve durağan olduğu kabul edilir (Mucuk ve Alptekin, 2008:168). Özdeğerlerin çemberin içinde mi yoksa üzerinde veya dışında mı olduğunda tereddüt hasıl olursa, karakteristik polinomun köklerinin, kök değerlerinin modullardaki karşılığının birden küçük olmasına bakılır. Birden küçük ise model istikrarlı ve durağan olarak kabul edilir, bire eşit veya büyük ise model istikrarlı ve durağan kabul edilmez.

\subsection{Etki -Tepki Analizi}

VAR modelinde bulunan ekonomik faktörlerin birbirlerini etkileme durumu olan Etkitepki analizi, modelde tüm değişkenler arasında bağımsız değişken olarak seçilen değişkenlerden birinde meydana gelen şokların diğer bağımlı değişken üzerindeki etkisini ortaya koymaktadır.

Etki-tepki analiz VAR modelinde rassal hata teriminde oluşacak bir standart sapmalık şokun, içsel değişken olarak yer alan değişkenlerin şimdiki ve gelecekteki değerlerinde meydana getireceği etkiyi ölçmektedir. Dinamik tepkileri görme ve oluşacak şoklara uyum sürecini incelemek etki-tepki analizinde temel amaçtır (Kayahan ve Hepaktan, 2016:183; Durmuş vd., 2019:880).

$\mathrm{Bu}$ sistemde diagonal yapı kullanılması ile oluşturulan üçgen dizilerle oluşan korelasyon etkisiyle değişimin sistemdeki tüm değişkenler üzerinde etkili olması sağlanmıştır. $\mathrm{Bu}$ yaklaşımla etki-tepki fonksiyonunun tanımlanması için vektör otoregresyon üzerine kısıt getirilmelidir. Kısıtlılık Choleski ayrıştırma yöntemi ile sağlanabilecektir. Serilerdeki sıçrayışların açıklanabilmesi ve tepkilerin görüntülenebilmesi açısında Choleski ayrıştırmasına dayalı etki-tepki fonksiyonun grafiklerinden yararlanmak kullanışlı bir 
yöntemdir. Etki-tepki fonksiyonlarının tanımlanmasında uygulamada genellikle bu yaklaşım kullanılmaktadır (Yıldız, 2014:47).

\subsection{Varyans Ayrıştırması}

Artıkların analizinde kullanılan teknik olan Varyans Ayrıştırması (Variance Decomposition) VAR modelinin tahmin edilmesiyle belirlenip öngörü hata varyansını ölçer. $\mathrm{Bu}$ teknik ile istatistiki şokların değişkenler üzerinde yapmış oldukları etkiler görülmüş olacaktır (Tarı ve Bozkurt, 2011:5).

Sims değişkendeki değişimin kaynağının hangi değişkendeki değişimlerden kaynaklandığını belirtmeye yarayan özet bir tablo geliştirmiştir. Tahmin hata varyansının hangi oranda her bir bağımsız değişkendeki şok tarafından açıklandığını belirlemeye çalışarak, istatistiki şokların değişkenler üzerinde yol açtığı sayısal etkiler görülmüş olur. Bir anlamda varyans ayrıştırması ile incelenen değişkenlerin her birinin varyansında oluşacak değişmenin \% kaçının kendi gecikme değerleriyle, \% kaçının ise diğer değişkenlerce açıklandığı araştırılır (Yıldız, 2014:47).

\section{AMPİRIK BULGULAR}

\subsection{Tanımlayıcı İstatistikler ve Korelasyon}

Finansal sistemden sağlanan getirileri temsilen incelenen getiri araçları ile ilgili bilgiler Tablo 2'de raporlanmıştır. Tüm veriler, Türkiye İstatistik Kurumu veri tabanından elde edilen aylara göre hesaplanmış dönemsel TÜFE bazlı reel getirilerin, doğal logaritmaları alınarak kullanılmıştır.

Tablo 2. Tanımlayıcı İstatistikler (\%)

\begin{tabular}{|lrrrrrr|}
\hline & BIST 100 & \multicolumn{1}{l}{ FAİZ } & \multicolumn{1}{c|}{ EURO } & DOLAR & ALTIN & \multicolumn{1}{c|}{ DIBS } \\
\hline A. Ortalama & 0,414560 & 0,170415 & 0,093005 & 0,186839 & 0,936580 & 0,219171 \\
Medyan & 0,490000 & 0,210000 & $-0,170000$ & $-0,32000$ & 0,560000 & 0,480000 \\
Maximum & 19,06000 & 3,060000 & 17,78000 & 19,27000 & 16,97000 & 11,10000 \\
Minimum & $-25,9300$ & $-4,48000$ & $-11,57000$ & $-10,3100$ & $-12,0900$ & $-9,55000$ \\
Std. Sap. & 6,524633 & 0,917435 & 3,424101 & 3,612809 & 4,636928 & 2,184187 \\
Çarpıklık & $-0,294100$ & $-0,620558$ & 0,788382 & 1,370916 & 0,598542 & 0,116666 \\
Basıklık & 4,356176 & 6,061813 & 7,042243 & 9,023121 & 4,388713 & 8,130280 \\
Jarque-Bera & 17,57259 & 87,77531 & 151,3917 & 352,1898 & 27,03234 & 212,0926 \\
Olasılık & 0,000153 & 0,000000 & 0,000000 & 0,000000 & 0,000001 & 0,000000 \\
Gözl. Say. & 193 & 193 & 193 & 193 & 193 & 193 \\
\hline
\end{tabular}

Minimum seviyede tüm değişkenler eksi değer almaktadır. En yüksek ortalama getiri altında bulunmaktadır. En düşük standart sapma faiz getirisinde bulunmaktadır. Faiz getirisinde volatilite düşük olmaktadır. En yüksek getiri ise BIST 100 endeks getirisinde görülmektedir. Araştırmada 193 adet gözlem kullanılmıştır. Bu gözlem sayısı zaman serisi analizlerinin serbestlik dereceleri ve güvenirlikleri için yeterli olmaktadır. İncelenen değişkenlere ait korelasyon matrisi Tablo 3’te özetlenmiştir. 
Tablo 3. Değişkenlere Ait Korelasyon Matrisi

\begin{tabular}{|c|c|c|c|c|c|c|}
\hline KORELASYON & BIST 100 & FAIZ & EURO & DOLAR & ALTIN & DIBS \\
\hline BIST 100 & 1,000000 & ÇZİ, AY, Tİ & ODİ, ZY, İİ & YDİ, ZY, İI & Zİ, ZY, İ̇ & ODİ, AY, Ti் \\
\hline FAİZ & 0,165122 & 1,000000 & ÇZİ, ZY, İI & ÇZİ, ZY, İI & ÇZİ, ZY, İİ & YDİ, AY, Tİ \\
\hline EURO & $-0,498502$ & $-0,139869$ & 1,000000 & YDİ, AY, Tİ & ODİ, AY, Tİ & ODİ, ZY İI \\
\hline DOLAR & $-0,612371$ & $-0,114700^{-}$ & 0,793568 & 1,000000 & ODİ, AY, Tİ & ODİ, ZY, İI \\
\hline ALTIN & $-0,380638$ & $-0,059953$ & 0,594079 & 0,577338 & 1,000000 & Zİ, ZY, İ \\
\hline DIBS & 0,468541 & 0,615978 & $-0,552016$ & $-0,552499$ & $-0,264560$ & 1,000000 \\
\hline
\end{tabular}

İki değişkenin birlikte hareket etme eğiliminin ölçüsünü ve yönünü belirleme korelasyon ile mümkündür. Korelasyon katsayıları $(-1,1)$ aralığında değişen değerler alır. Katsayıların \pm 1 'e doğru yaklaşması, değişkenler arasında güçlü bir ilişki olduğunu belirtir. Katsayıların işaretinin pozitif olması; değişkenler arasındaki doğrusal ilişkinin aynı yönlü, katsayıların negatif olması ise; değişkenlerin zıt yönlü hareket ettiğini gösterir (Cihangir vd., 2020:928).

Bu bilgilere göre; ÇZİ (Çok Zayıf İlişki), Zİ (Zayıf İlişki), ODİ (Orta Düzeyde İlişki), YDİ (Yüksek Düzeyde İlişki), AY (Aynı Yönlü), ZY (Zıt Yönlü), Tİ (Tamamlayıcılık İlişkisi) ve İİ (İkame İlişkisi) olarak değerlendirilip, korelasyon tablosunda değişkenler arasındaki ilişkiler düzenlenmiştir. Örneğin BIST 100 endeks getirisi ile faiz getirisi arasında (ÇZİ, AY, Tİ) çok zayıf bir ilişki bulunmakta, ilişkinin yönü pozitif olduğundan aynı yönlü ve birbirlerini tamamlayıcılık ilişkisine sahiptirler, denilebilir. Değişkenlerin birbirleriyle farklı şekillerde ilişkili oldukları tablodan anlaşılmaktadır. Değişkenler korelasyon matris sisteminde karşılık gelen ifadelere göre açıklanabilir.

\subsection{Durağanlık Testi Sonuçları}

Durağanlık testi sonuçları için ADF (Augmented Dickey-Fuller) ile PP (PhilipsPerron) birim kök testleri kullanılmıştır. Birim kök test sonuçları, Tablo 4'te sunulmuştur.

Tablo 4. ADF ve P P Birim Kök Testi Sonuçları

\begin{tabular}{|c|c|c|c|c|c|c|}
\hline & \multicolumn{6}{|c|}{ BIST 100} \\
\hline & \multicolumn{2}{|c|}{ Sabitsiz \&Trendsiz Model } & \multicolumn{2}{|c|}{ Sabitli Model } & \multicolumn{2}{|c|}{ Sabitli ve Trendli Model } \\
\hline & t-istatiği & Ola. (p) değ. & t-istatiği & Ola. (p) değ. & t-istatiği & Ola. (p) değ. \\
\hline ADF test ist. & $-10,5723$ & $0,0000^{* * *}$ & $-10,5705$ & $0,0000^{* * *}$ & $-10,5444$ & $0,0000^{* * *}$ \\
\hline \multirow[t]{4}{*}{ P- P Testi } & $-10,4759$ & $0,0000^{* * *}$ & $-10,47251$ & $0,0000^{* * *}$ & $-10,44375$ & $0,0000^{* * *}$ \\
\hline & \multicolumn{6}{|c|}{ ALTIN } \\
\hline & \multicolumn{2}{|c|}{ Sabitsiz \&Trendsiz Model } & \multicolumn{2}{|c|}{ Sabitli Model } & \multicolumn{2}{|c|}{ Sabitli ve Trendli Model } \\
\hline & t-istatiği & Ola. (p) değ. & t-istatiği & Ola. (p) değ. & t-istatiği & Ola. (p) değ. \\
\hline ADF test ist. & \multirow{2}{*}{$\begin{array}{l}-10,8262 \\
-10,72579\end{array}$} & $0,0000^{* * *}$ & \multirow{2}{*}{$\begin{array}{l}-10,42521 \\
-11,10789\end{array}$} & $0,0000^{* * *}$ & \multirow{2}{*}{$\begin{array}{l}-10,38916 \\
-11,06934\end{array}$} & $0,0000^{* * *}$ \\
\hline P- P Testi & & $0,0000^{* * *}$ & & $0,0000^{* * *}$ & & $0,0000^{* * *}$ \\
\hline
\end{tabular}




\begin{tabular}{|c|c|c|c|c|c|c|}
\hline & \multicolumn{6}{|c|}{ DIBS } \\
\hline & \multicolumn{2}{|c|}{ Sabitsiz \&Trendsiz Model } & \multicolumn{2}{|c|}{ Sabitli Model } & \multicolumn{2}{|c|}{ Sabitli ve Trendli Model } \\
\hline & t-istatiği & Ola. (p) değ. & t-istatiği & Ola. (p) değ. & t-istatiği & Ola. (p) değ. \\
\hline ADF test ist. & $-8,905234$ & $0,0000^{* * *}$ & $-8,948719$ & $0,0000^{* * *}$ & $-9,102047$ & $0,0000^{* * *}$ \\
\hline \multirow[t]{4}{*}{ P- P Testi } & $-8,421953$ & $0,0000^{* * *}$ & $-8,423839$ & $0,0000^{* * *}$ & $-8,481008$ & $0,0000^{* * *}$ \\
\hline & \multicolumn{6}{|c|}{ FAiz } \\
\hline & \multicolumn{2}{|c|}{ Sabitsiz \&Trendsiz Model } & \multicolumn{2}{|c|}{ Sabitli Model } & \multicolumn{2}{|c|}{ Sabitli ve Trendli Model } \\
\hline & t-istatiği & Ola. (p) değ. & t-istatiği & Ola. (p) değ. & t-istatiği & Ola. (p) değ. \\
\hline ADF test ist. & $-8,092064$ & $0,0000^{* * *}$ & $-9,548633$ & $0,0000^{* * *}$ & $-8,092064$ & $0,0000^{* * *}$ \\
\hline \multirow[t]{4}{*}{ P- P Testi } & $-9,466117$ & $0,0000^{* * *}$ & $-9,754707$ & $0,0000^{* * *}$ & $-10,13352$ & $0,0000^{* * *}$ \\
\hline & \multicolumn{6}{|c|}{ EURO } \\
\hline & \multicolumn{2}{|c|}{ Sabitsiz \&Trendsiz Model } & \multicolumn{2}{|c|}{ Sabitli Model } & \multicolumn{2}{|c|}{ Sabitli ve Trendli Model } \\
\hline & t-istatiği & Ola. (p) değ. & t-istatiği & Ola. (p) değ. & t-istatiği & Ola. (p) değ. \\
\hline ADF test ist. & $-10,78474$ & $0,0000^{* * *}$ & $-10,60526$ & $0,0000^{* * *}$ & $-10,78474$ & $0,0000^{* * *}$ \\
\hline \multirow[t]{4}{*}{ P- P Testi } & $-10,34491$ &, $.0000^{* * *}$ & $-10,32213$ & $0,0000^{* * *}$ & & $0,0000^{* * *}$ \\
\hline & \multicolumn{6}{|c|}{ DOLAR } \\
\hline & \multicolumn{2}{|c|}{ Sabitsiz \&Trendsiz Model } & \multicolumn{2}{|c|}{ Sabitli Model } & \multicolumn{2}{|c|}{ Sabitli ve Trendli Model } \\
\hline & t-istatiği & Ola. (p) değ. & t-istatiği & Ola. (p) değ. & t-istatiği & Ola. (p) değ. \\
\hline ADF test ist. & $-10,50788$ & $0,0000^{* * *}$ & $-10,41388$ & $0,0000^{* * *}$ & $-10,50788$ & $0,0000^{* * *}$ \\
\hline P- P Testi & $-9,286967$ & $0,0000^{* * *}$ & $-9,228182$ & $0,0000^{* * *}$ & $-9,179772$ & $0,0000^{* * *}$ \\
\hline
\end{tabular}

$* * *, * * *$ sirasıyla $\% 1, \% 5$ ve $\% 10$ anlamlılık düzeyinde istatistiksel olarak p değerlerinin anlamlı olduğunu göstermektedir.

Tablo 4'te görülebileceği gibi analizde kullanılan BIST 100 endeksi, altın, DIBS, faiz, euro ve dolar getiri değişkenlerinin hesaplanan $\mathrm{p}$ değerleri 0.05 kritik değerden küçük olduğundan düzeyde I (0) durağandırlar.

\subsection{VAR Modeli}

Durağanlık testlerinin yapılmasından ardından kurulacak VAR modelinde uygun gecikme uzunluğu tahmin edilmelidir.

Tablo 5. Uygun Gecikme Uzunluğu Seçimi

\begin{tabular}{|ccccccc|}
\hline Lag & LogL & LR & FPE & AIC & SC & HQ \\
\hline 0 & $-1539,102$ & NA & $1,700153^{*}$ & $17,55798^{*}$ & $17,66606^{*}$ & $17,60182^{*}$ \\
1 & $-1509,244$ & 57,34109 & 1,823511 & 17,62777 & 18,38437 & 17,93464 \\
2 & $-1476,805$ & $60,08554^{*}$ & 1,901413 & 17,66824 & 19,07334 & 18,23814 \\
3 & $-1462,765$ & 25,04925 & 2,448779 & 17,91778 & 19,97139 & 18,75072 \\
4 & $-1443,749$ & 32,62909 & 2,989573 & 18,11079 & 20,81291 & 19,20675 \\
5 & $-1421,078$ & 37,35607 & 3,515784 & 18,26225 & 21,61288 & 19,62125 \\
6 & $-1399,782$ & 33,63761 & 4,221812 & 18,42934 & 22,42848 & 20,05137 \\
7 & $-1369,358$ & 45,98175 & 4,599571 & 18,49271 & 23,14035 & 20,37777 \\
8 & $-1341,868$ & 39,67294 & 5,221173 & 18,58941 & 23,88556 & 20,73751 \\
\hline
\end{tabular}

VAR modeli için uygun gecikme uzunluğu seçimi kriteri olan, AIC, SC, HQ ve FPE kriterleri sıfır gecikmeyi uygun görürken, sıfır gecikmeye en yakın olan gecikme uzunluğu 1 
alındığında modelin kalıntı değerlerinde 2. gecikmede serisel korelasyon gözlenmiştir. Bu nedenle Tablo 5' te görüldüğü üzere LR: ardışık düzeltilmiş LR kriterine bakılarak en uygun gecikme uzunluğunun 2 olduğu görülmüştür. 1 gecikmeli modelde 2 . gecikmede serisel korelasyon meydana geldiğinden 2 gecikmeli VAR (2) modeli ile analiz yapılmıştır (Sever ve Demir, 2007:56). VAR modelinin tahmin edilmesinden sonra, bu model esas alınarak yapılacak analizlerin geçerliliğinin doğru sonuçlar vermesi için, modelin durağan veya istikrar olması gerekir. Buda katsayı matrislerinin hepsinin birim çember içinde olmasını gerektirmektedir (Mucuk ve Alptekin, 2008:168). Ayrica modelde serisel korelasyon ve değişen varyans sorunu olmadığı görülmüşsür.

Grafik 1'de görüldüğü üzere tüm noktalar açık bir şekilde birim çember içindedir.

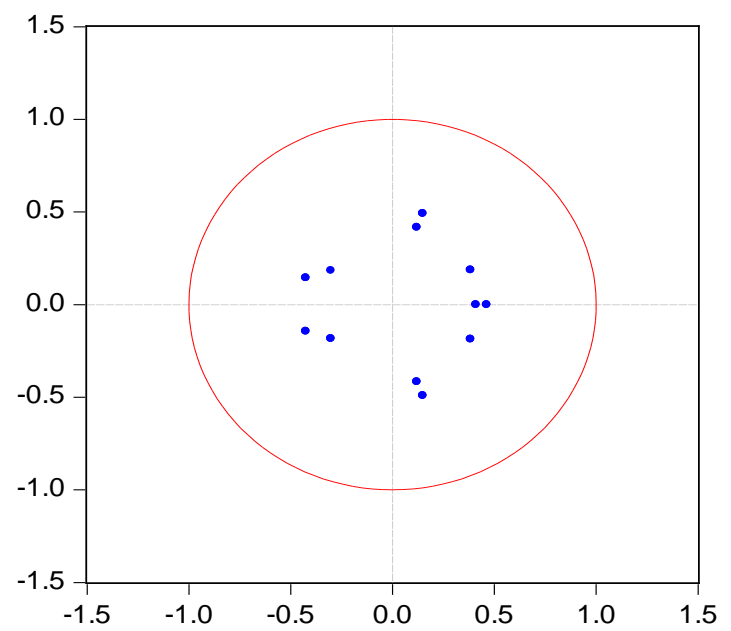

Grafik 1. AR Karakteristik Polinomun Ters Kökleri

Tablo 6' da sekiz gecikme uzunluğuna kadar yer alan tüm gecikme uzunluklarında değişkenler arasındaki otokorelasyon olasılık değeri $\mathrm{p}>0.05$ olduğu görüldüğünden, değişkenler arasında otokorelasyon yoktur şeklinde kurulan $\mathrm{H}_{0}$ hipotezi geçerlidir.

Tablo 6. LM Testi Sonuçları

\begin{tabular}{|ccccc|}
\hline Gecikme Uzunluğu & LRE* $^{*}$ İstatistiği & Olasılık & Rao F İstat. & Olasılık \\
\hline 1 & 29,25641 & 0,7795 & 0,809913 & 0,7797 \\
2 & 60,90704 & 0,8213 & 0,841178 & 0,8220 \\
3 & 107,7264 & 0,4893 & 0,997268 & 0,4926 \\
4 & 139,8486 & 0,5822 & 0,967997 & 0,5886 \\
5 & 173,4626 & 0,6231 & 0,957959 & 0,6340 \\
6 & 203,2460 & 0,7237 & 0,930348 & 0,7390 \\
7 & 261,0455 & 0,3344 & 1,034803 & 0,3626 \\
8 & 312,4815 & 0,1538 & 1,090939 & 0,1828 \\
\hline
\end{tabular}

Tablo 7'de söz konusu modelde değişen varyans sorununun olup olmadığı için yapılan White Değişen Varyans Testinde olasılık değeri $\mathrm{p}>0.05$ olduğu görüldüğünden modelde değişen varyans sorununun bulunmadığı anlaşılmıştır. 
Tablo 7. Değişen Varyans Testi

\begin{tabular}{|ccc|}
\hline Ki Kare & Serbestlik Derecesi & Olasılık Değeri \\
\hline 519,1640 & 504 & 0,3107 \\
\hline
\end{tabular}

\subsubsection{Etki-Tepki Analizi}

VAR modelinde bulunan değişkenlerin birbirlerini etkileme durumu olan etki-tepki analizi VAR modelinde rassal hata terimlerinden birinde meydana gelen bir standart sapmalık şoka karşılık, içsel değişken olarak yer alan değişkenlerin şimdi ve gelecekte verecekleri etkiyi ölçmektedir. Finansal getiri araçlarından birine gelecek bir standart sapmalık şoka diğer getiri araçlarının vermiş oldukları tepkiler, her bir değişken genelinde aşağıda grafiklerle açıklanmıştır. LNBIST 100 endeks getirisinde meydana gelen bir artış şoku karşısında diğer finansal araçların verdikleri tepkiler Grafik 2'de yer almaktadır.

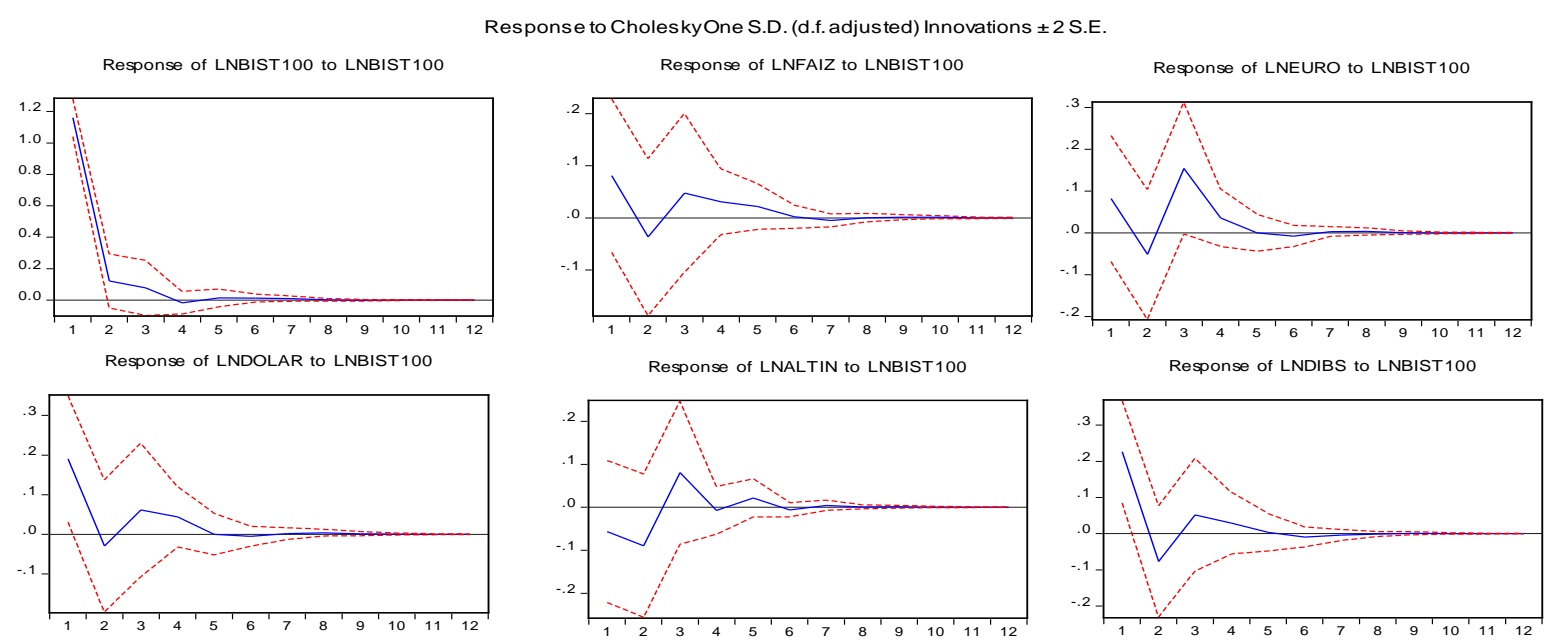

Grafik 2. LNBIST 100 Etki-Tepki Analizi

Grafik 2'de görüldüğü üzere; BIST 100 endeks getirisine verilecek bir standart sapmalık şok kendisini ilk dönemde pozitif ve yüksek getiri olarak etkilemekte, ikinci dönemde getiri azalmakta ve dördüncü dönemde dengeye gelip negatif değer almamaktadır. BIST 100 endeks getirisine verilecek bir standart sapmalık şok karşısında faiz, altın, dolar ve DIBS getirileri benzer tepkiler verip, ilk dönemde artış ve sonrasında gelen ikinci dönemde negatif değere düşüp, üç ve dördüncü dönemlerde dengeye gelmektedir. Dolayısıyla BIST 100 endeks getirisi bu değiş̧enlerle hem tamamlayıcılık ve hem de ikame ilişkisi içinde bulunmaktadır. BIST 100 endeks getirisine verilecek bir standart sapmalık şok karşısında ilk dönemde negatif tepkiyi altın getirisi vermektedir. İlk dönemde tepki negatif olup, sonraki üç ve dördüncü dönemler arasında altın getirisi yükselip daha sonra dengeye gelmektedir. Dolayısıyla BIST 100 endeks getirisinde meydana gelen bir standart sapmalık şoka ilk dönemde negatif tepki veren sadece altın getirisidir. Buna göre BIST 100 endeks getirisi ile altın getirisi arasında ikame bir ilişki var denilebilir. LNFAİZ getirisinde meydana gelen bir artış şoku karşısında diğer finansal araçların verdikleri tepkiler Grafik 3'te yer almaktadır. 
Response to Cholesky One S.D. (d.f. adjusted) Innovations \pm 2 S.E

Response of LNFAIZ to LNFAIZ

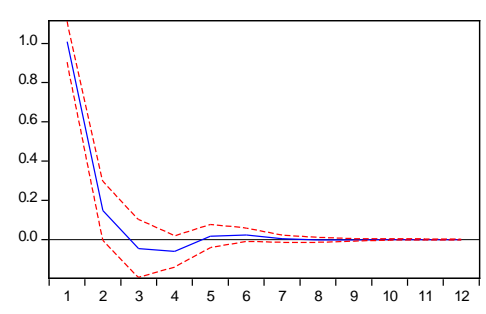

Response of LNDOLAR to LNFAIZ

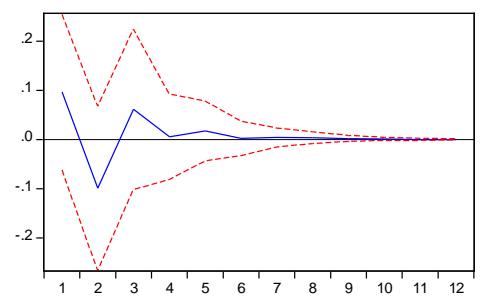

Response of LNBIST100 to LNFAIZ

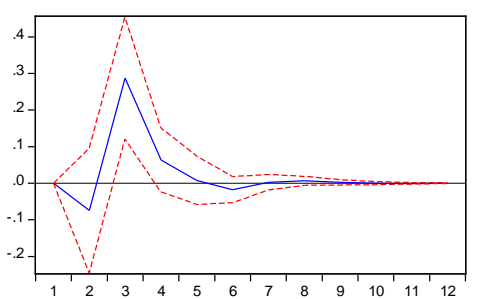

Response of LNALTIN to LNFAIZ

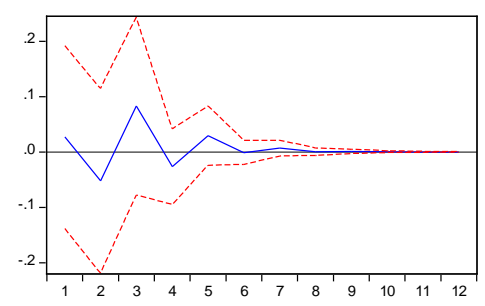

Response of LNEURO to LNFAIZ

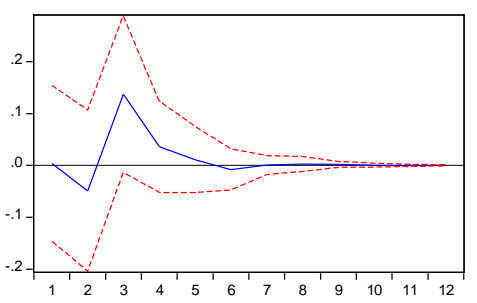

Response of LNDIBS to LNFAIZ

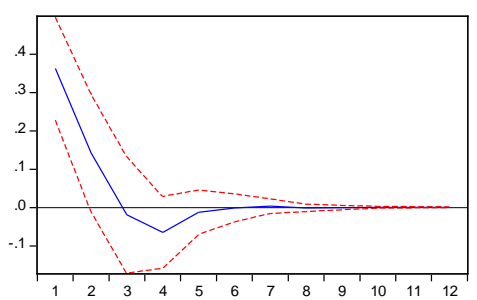

Grafik 3. LNFAİZ Etki-Tepki Analizi

Grafik 3’te görüldüğü üzere; faiz getirisine verilecek bir standart sapmalık şok kendisini ilk dönemde pozitif ve yüksek getiri olarak etkilemekte, üç ve beşinci dönemler arasında negatif getiri olmakta ve bundan sonra dengeye gelmektedir. Faiz getirisine verilecek bir standart sapmalık şok karşısında BIST 100 endeks ve euro getirisi ilk dönemde tepki vermeyip, ikinci dönemde negatif tepki, daha sonra pozitif tepkiye dönüşüp yedinci dönemde dengeye gelmektedirler. Faiz getirisine verilecek bir standart sapmalık şok karşısında dolar ve altın getirileri ilk dönemde verilecek pozitif tepki ile birlikte ikinci dönemde negatif tepki vermekte daha sonra tekrar pozitif olan tepki dengeye gelmektedir. Altın getirisinin vermiş olduğu tepki dolar getirisine göre daha fazla inişli ve çıkışlı olmakta buda altın getirisinin faiz getirilerindeki şoklardan daha fazla etkilendiğini ve dengeye gelmek için uzun bir dönemin geçmiş olmasını göstermektedir. Faiz getirisine verilecek bir standart sapmalık şok karşısında DIBS getirisi ilk üç dönemde yüksek bir pozitif getiri ile tepki vermekte, bu tepki daha sonra üç ve beşinci dönemlerde negatif tepkiye dönüşüp beşini dönemde dengeye gelmektedir. LNEURO getirisinde meydana gelen bir artış şoku karşısında diğer finansal araçların verdikleri tepkiler Grafik 4’te yer almaktadır. 


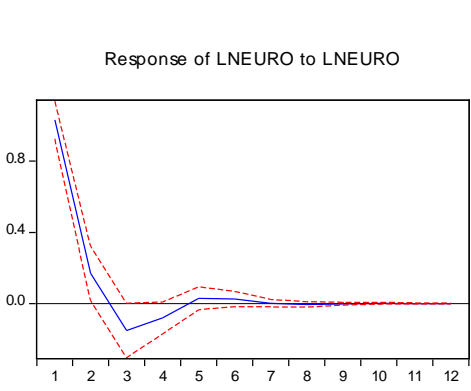

Response to Cholesky One S.D. (d.f. adjusted) Innovations \pm 2 S.E

Response of LNDOLAR to LNEURO

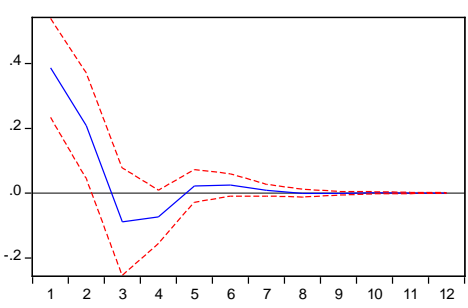

Response of LNBIST100 to LNEURO

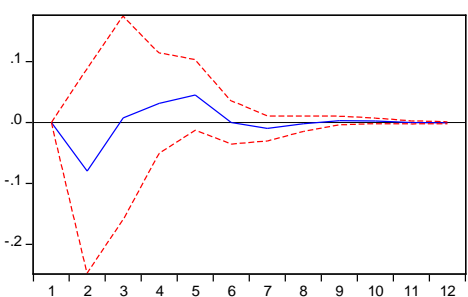

Response of LNALTIN to LNEURO

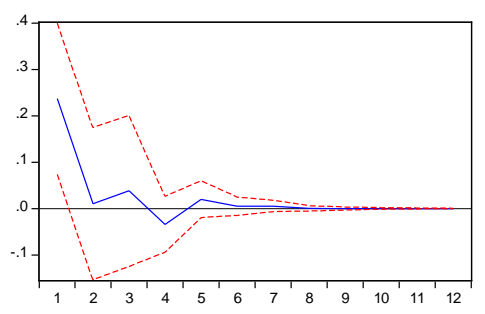

Response of LNFAIZ to LNEURO

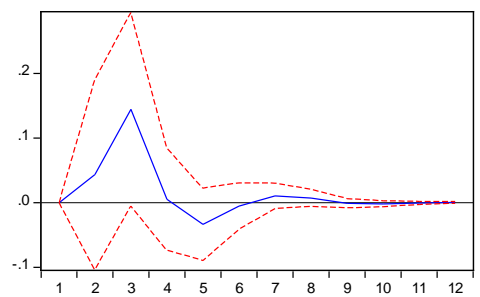

Response of LNDIBS to LNEURO

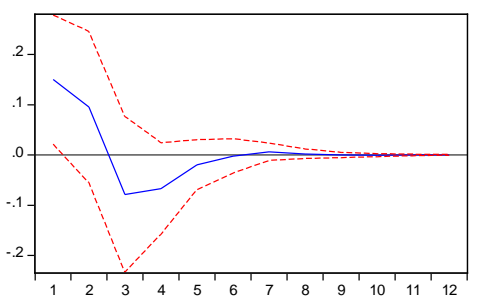

Grafik 4. LNEURO Etki-Tepki Analizi

Grafik 4’te görüldüğü üzere; euro getirisine verilecek bir standart sapmalık şok kendisini ilk iki dönemde pozitif ve yüksek getiri olarak etkilemekte, iki ve beşinci dönemler arasında negatif getiri olmakta ve bundan sonra dengeye gelmektedir. Euro getirisine verilecek bir standart sapmalık şok karşısında BIST 100 endeks getirisi ilk dönmede negatif tepkiden sonra üçüncü ve altıncı dönemlerde pozitif ve daha sonra dokuzuncu döneme kadar düşük bir negatif tepkiden sonra dengeye gelmektedir. Euro getirisine verilecek bir standart sapmalık şok karşısında faiz getirisi ilk dönemde pozitif, daha sonra negatif tepki ve pozitif tepki ile dengeye gelmektedir. Daha çok pozitif yönlü bir tepki tamamlayıcılık etkisinin daha fazla olduğu görülmektedir. Euro getirisine verilecek bir standart sapmalık şok karşısında dolar ve DIBS getirisi benzer tepkiler göstermekte, ilk dönemde pozitif tepki, daha sonra negatif tepkiden sonra dengeye gelmektedirler. Euro getirisine verilecek bir standart sapmalık şok karşısında altın getirisi yüksek bir pozitif tepki ile birlikte az bir dönem negatif tepkiden sonra dengeye gelmektedir. Burada dikkat çekici nokta euro getirisine verilecek bir standart sapmalık şok karşısında ilk dönemde sadece BIST 100 endeks getirisinin negatif tepki vermesidir. $\mathrm{Bu}$ da aralarındaki ikame ilişkisini göstermektedir. LNDOLAR getirisinde meydana gelen bir artış şoku karşısında diğer finansal araçların verdikleri tepkiler Grafik 5 'te yer almaktadır. 
Response to Cholesky One S.D. (d.f. adjusted) Innovations \pm 2 S.E

Response of LNDOLAR to LNDOLAR
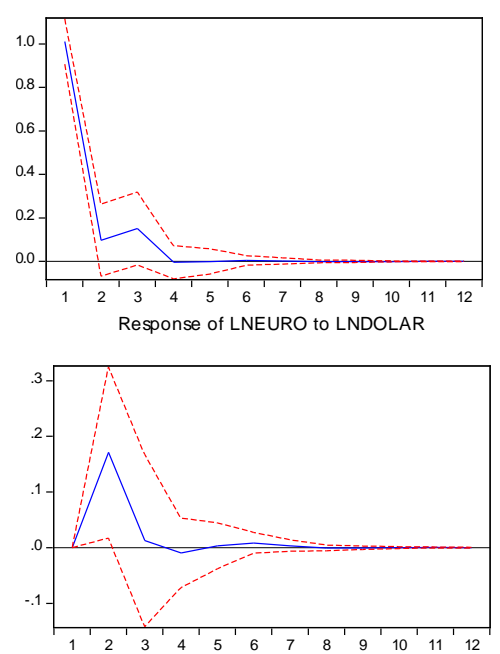

Response of LNBIST100 to LNDOLAR
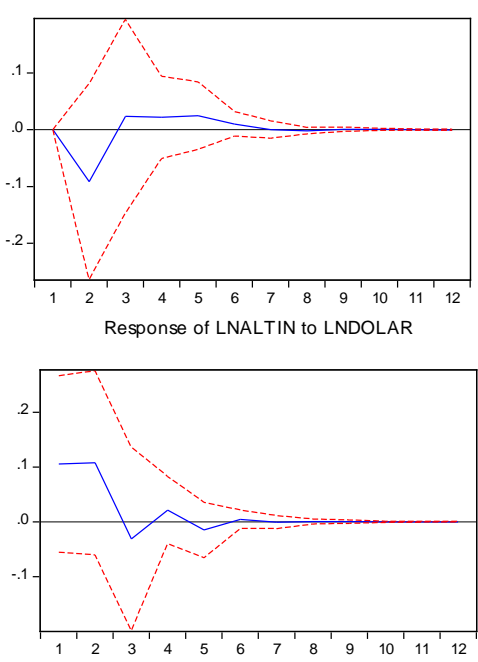

Response of LNFAIZ to LNDOLAR

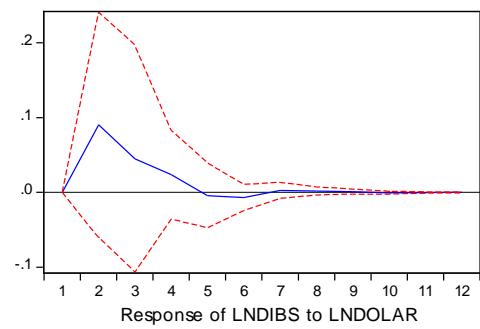

Response of LNDIBS to LNDOLAR

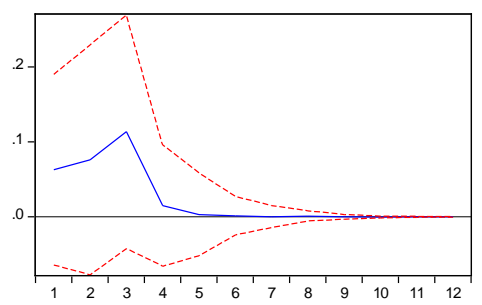

Grafik 5. LNDOLAR Etki-Tepki Analizi

Grafik 5'te görüldüğ̈̈ üzere; dolar getirisine verilecek bir standart sapmalık şok kendisini dördüncü döneme kadar pozitif ve yüksek getiri olarak etkilemekte ve bundan sonra dengeye gelmektedir. Dolar getirisine verilecek bir standart sapmalık şok karşısında faiz, euro, altın ve DIBS getirileri benzer tepkiler göstermekte, yüksek pozitif getiri ile birlikte dolar getirisinin düşük bir negatif getiri tepkisi haricinde, tüm bu değişkenler pozitif tepki ile dengeye gelmektedirler. Dolar getirisine verilecek bir standart sapmalık şok karşısında DIBS100 endeks getirisi ilk dönemde negatif bir tepki vermekte daha sonra düşük bir pozitif tepkiden sonra dengeye gelmektedir. Bu durum dolar getirisi ile BIST 100 endeks getirisi arasındaki ikame ilişkisini ortaya koymaktadır. LNALTIN getirisinde meydana gelen bir artış şoku karşısında diğer finansal araçların verdikleri tepkiler Grafik 6'da yer almaktadır.

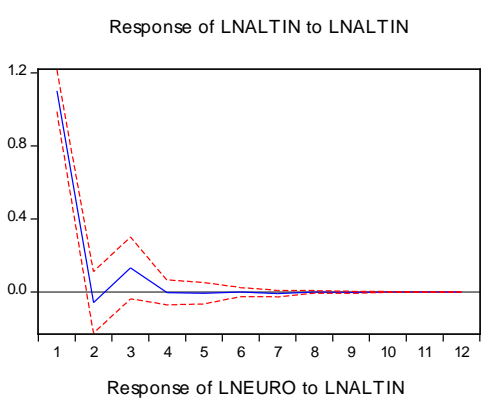

Response to Cholesky One S.D. (d.f. adjusted) Innovations \pm 2 S.E

Response of LNEURO to LNALTIN

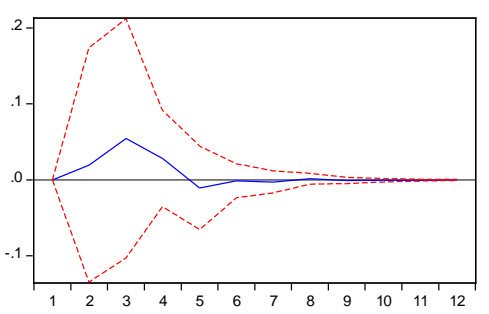

Response of LNBIST100 to LNALTIN

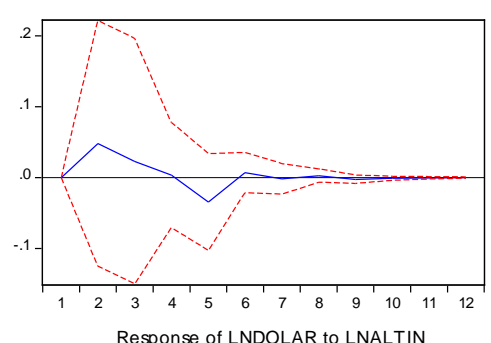

Response of LNDOLAR to LNALTIN

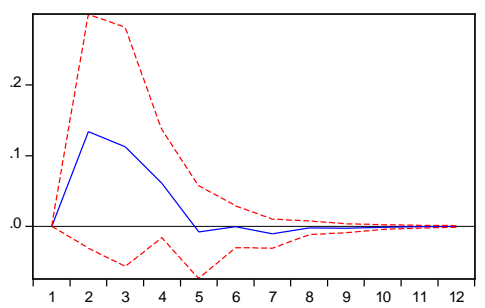

Response of LNFAIZ to LNALTIN

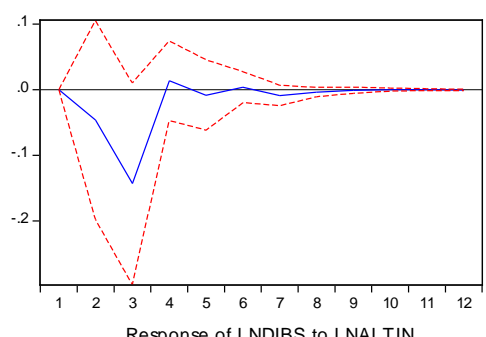

Response of LNDIBS to LNALTIN

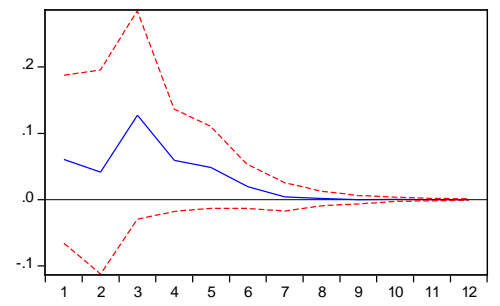

Grafik 6. LNALTIN Etki-Tepki Analizi 
Grafik 6'da görüldüğü üzere; altın getirisine verilecek bir standart sapmalık şok kendisini ikinci döneme kadar pozitif ve yüksek getiri olarak etkilemekte ve bundan sonra dengeye gelmektedir. İkinci dönemin başında düşük oranda negatif etki kısa bir sürede tekrar pozitif olmaktadır. Altın getirisine verilecek bir standart sapmalık şok karşısında BIST100 endeks, euro ve dolar getirileri benzer tepkiler vermekte, birinci dönemde oluşan pozitif tepki daha sonra dört ve beşinci dönemlerde düşük negatif tepki ile birlikte yedinci dönemden itibaren dengeye gelmektedir. Altın getirisine verilecek bir standart sapmalık şok karşısında faiz getirisi negatif tepkiden sonra dengeye gelmekte, DIBS getirisi ise pozitif tepkiden sonra dengeye gelmektedir. Buna göre altın getirisi ile faiz getirisi arasında ikame ilişkisi, altın getirisi ile DIBS getirisi arasında tamamlayıcılık ilişkisi var denilebilir. Dolayısıyla korelasyon matrisinde altın getirisi ile DIBS getirisi arasında ortaya çıkan ikame etkisi, altın getirisine verilecek bir standart sapmalık şok karşısında DIBS getirisinin tepkisi, etki-tepki analizinde tamamlayıcı bir etki olarak görülmektedir. LNDIBS getirisinde meydana gelen bir artış şoku karşısında diğer finansal araçların verdikleri tepkiler Grafik 7'de yer almaktadır.

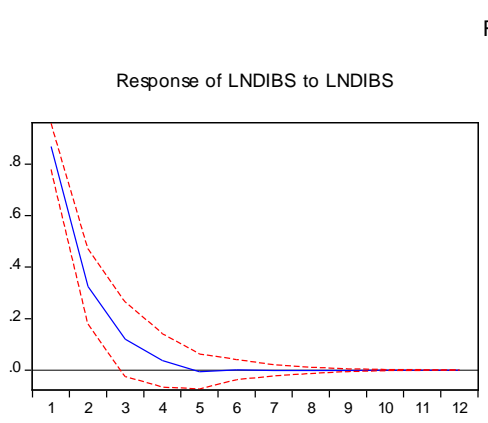

Response to CholeskyOne S.D. (d.f. adjusted) Innovations \pm 2 S.E.

Response of LNEURO to LNDIBS

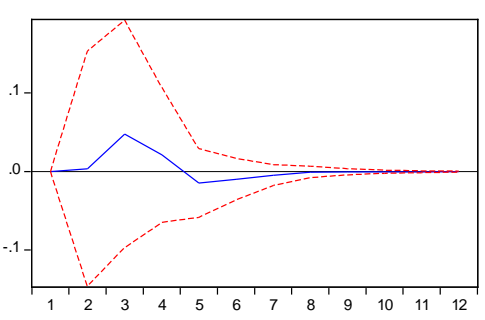

Response of LNBIST100 to LNDIBS

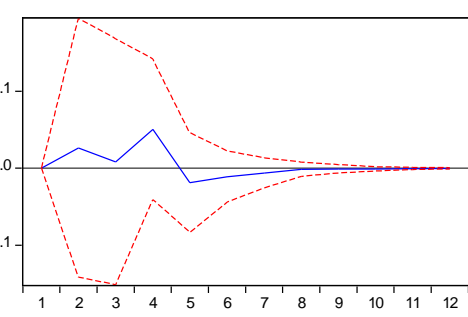

Response of LNDOLAR to LNDIBS

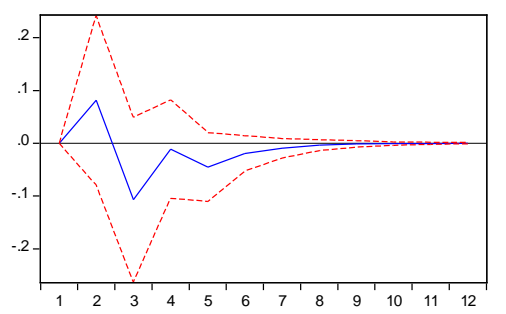

Response of LNFAIZ to LNDIBS

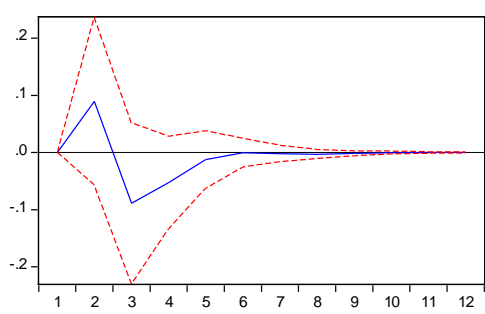

Response of LNALTIN to LNDIBS

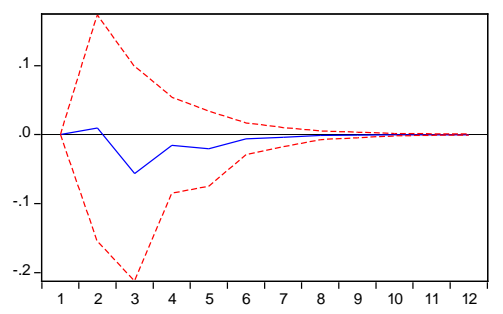

Grafik 7. LNDIBS Etki-Tepki Analizi

Grafik 7'de görüldüğü üzere; DIBS getirisine verilecek bir standart sapmalık şok kendisini beşinci döneme kadar pozitif ve yüksek getiri olarak etkilemekte ve bundan sonra dengeye gelmektedir. DIBS getirisine verilecek bir standart sapmalık şok karşısında diğer değişkenlerde görülen ortak özellik, ilk dönemde hiçbir değişken getirisinde negatif etkinin olmaması ve sonrasinda ise hepsinin negatif tepki sonrası dengeye gelmeleridir. DIBS getiri değişkenin risksiz ve öngörülebilir getiri sağlaması tüm getiri değişkenlerinde benzer tepkilere yol açmaktadır. DIBS getirisine verilecek bir standart sapmalık şok karşısında faiz ve dolar getirileri daha fazla pozitif ve negatif tepki vermişlerdir. Bu yüzden DIBS, faiz ve dolar getirilerinin daha çok birbirleriyle etkileşim içinde oldukları belirtilebilir. 


\subsubsection{Varyans Ayrıştırması}

Araştırmada, her bir finansal araçtan elde edilen getiride meydana gelen değişimlerin ne kadarının kendinden, ne kadarının diğer finansal araçlardan kaynaklandığını eşanlı olarak analiz edebilmek için Varyans ayrıştırması analizleri yapılmış ve sonuçlar aşağıda açıklanmıştır. LNBIST 100 endeks getirisinde meydana gelen değişimlere yönelik varyans ayrıştırma sonuçları Tablo 8'de yer almaktadır.

Tablo 8. LNBIST 100 endeks Varyans Ayrıştırması

\begin{tabular}{|cccccccc|}
\hline Dönem & S.E. & LNBIST 100 & LNFAIZ & LNEURO & LNDOLAR & LNALTIN & LNDIBS \\
\hline 1 & 1,160647 & 100,0000 & 0,000000 & 0,000000 & 0,000000 & 0,000000 & 0,000000 \\
---- & -- & --- & -- & -- & --- & --- \\
12 & 1,220192 & 91,91339 & 6,232212 & 0,641367 & 0,677646 & 0,277169 & 0,258219 \\
$\mathbf{1 3}$ & $\mathbf{1 , 2 2 0 1 9 2}$ & $\mathbf{9 1 , 9 1 3 3 8}$ & $\mathbf{6 , 2 3 2 2 1 4}$ & $\mathbf{0 , 6 4 1 3 6 8}$ & $\mathbf{0 , 6 7 7 6 4 6}$ & $\mathbf{0 , 2 7 7 1 6 9}$ & $\mathbf{0 , 2 5 8 2 1 9}$ \\
14 & 1,220192 & 91,91338 & 6,232215 & 0,641369 & 0,677646 & 0,277170 & 0,258219 \\
\hline
\end{tabular}

Araştırmaya dahil edilen finansal sistemden sağlanan finansal getiri araçlarından BIST 100 endeks getirisi, 13. dönemde maksimum getiri seviyesine ulaşmıştır. Tablo 8'de bu seviyede meydana gelen değişimlerin \%91,91'lik kısmının kendi gecikmeli değerleriyle, \%6,2 kadarlık kısmının faiz ve geri kalan değişkenlerdeki (euro, dolar, altın, DIBS) açıklama kısmının ise \%1' den küçük olduğu görülmektedir. Dolayısıyla BIST 100 Endeks getirisi, $\% 6,2$ oranında faiz getirisi ile açıklanmakta, bunun dişındaki diğer finansal araç getirilerinden etkilenmemekte, daha çok kendi getiri değerleriyle açıklanmaktadır. LNFAİZ getirisinde meydana gelen değişimlere yönelik varyans ayrıştırma sonuçları Tablo 9'da yer almaktadır.

Tablo 9. LNFAİZ Varyans Ayrıştırması

\begin{tabular}{|cccccccc|}
\hline Dönem & S.E. & LNFAIZ & LNBIST 100 & LNEURO & LNDOLAR & LNALTIN & LNDIBS \\
\hline 1 & 1,011267 & 99,35408 & 0,645918 & 0,000000 & 0,000000 & 0,000000 & 0,000000 \\
--- & --- & --- & --- & --- & --- & -- & --- \\
12 & 1,064413 & 92,19489 & 1,031863 & 2,134716 & 0,954647 & 2,022683 & 1,661200 \\
$\mathbf{1 3}$ & $\mathbf{1 , 0 6 4 4 1 3}$ & $\mathbf{9 2 , 1 9 4 8 8}$ & $\mathbf{1 , 0 3 1 8 6 3}$ & $\mathbf{2 , 1 3 4 7 2 1}$ & $\mathbf{0 , 9 5 4 6 4 8}$ & $\mathbf{2 , 0 2 2 6 8 4}$ & $\mathbf{1 , 6 6 1 2 0 0}$ \\
14 & 1,064413 & 92,19488 & 1,031863 & 2,134721 & 0,954648 & 2,022684 & 1,661200 \\
\hline
\end{tabular}

Finansal getiri araçlarından faiz getirisi öngörü hata tahminine göre 13. dönemde dengeye gelmiştir. Tablo 9'da görüldüğü üzere faiz getirisinde meydana gelecek olan bir standart sapmalık şok \%92,19 oranında kendi gecikmeli değerleriyle \%1,03'ü BIST 100 endeks getirisi, \%2,13'ü euro getirisi, \%2,02'si altın getirisi ve \%1,6's1 DIBS getirisi ile açıklanmaktadır. Faizdeki getirilerin büyük bir kısmı yine kendi değerleri ile açıklanmıştır. İlk dönemde faiz getirisinin varyansı kendi gecikmeli değeri haricinde sadece BIST 100 endeks getirisi ile açıklanmaktadır. LNEURO getirisinde meydana gelen değişimlere yönelik varyans ayrıştırma sonuçları Tablo 10'da yer almaktadır. 
Tablo 10. LNEURO Varyans Ayrıştırması

\begin{tabular}{|cccccccc|}
\hline Dönem & S.E. & LNEURO & LNBIST100 & LNFAIZ & LNDOLAR & LNALTIN & LNDIBS \\
\hline 1 & 1,034770 & 99,36729 & 0,631430 & 0,001278 & 0,000000 & 0,000000 & 0,000000 \\
--- & -- & -- & --- & -- & -- & --- & --- \\
10 & 1,103778 & 92,25503 & 2,840325 & 1,871952 & 2,430894 & 0,349722 & 0,252080 \\
$\mathbf{1 1}$ & $\mathbf{1 , 1 0 3 7 7 8}$ & $\mathbf{9 2 , 2 5 4 9 9}$ & $\mathbf{2 , 8 4 0 3 2 4}$ & $\mathbf{1 , 8 7 1 9 5 2}$ & $\mathbf{2 , 4 3 0 8 9 9}$ & $\mathbf{0 , 3 4 9 7 4 3}$ & $\mathbf{0 , 2 5 2 0 9 0}$ \\
12 & 1,103778 & 92,25499 & 2,840327 & 1,871952 & 2,430899 & 0,349744 & 0,252091 \\
\hline
\end{tabular}

Finansal getiri araçlarından euro getirisi öngörü hata tahminine göre 11. dönemde dengeye gelmiştir. Tablo 10'da görüldüğü üzere euro getirisinde meydana gelecek olan bir standart sapmalık şok \%92 oranında kendi gecikmeli değerleriyle \%2,8'i BIST 100 endeks getirisi, \%1,8'i faiz getirisi, \%2,4'ü dolar getirisi, \%03'ü altın getirisi ve \%02'si DIBS getirisi ile açıklanmaktadır. Euro'daki getirilerin büyük bir kısmı yine kendi değerleri ile açıklanmıştır. BIST 100 endeks getirisi, faiz getirisi ve dolar getirisi az oranda da olsa eurodaki getirileri etkilemektedir. İlk dönemde euro getirisinin varyansı kendi gecikmeli değeri haricinde BIST 100 endeks getirisi ve çok küçük oranda faiz getirisi ile açıklanmaktadır. Yukarıda açıklanan varyans ayrıştırma analizlerinde BIST 100 getirisinin en etken getiri değişkeni olduğu görülmektedir. LNDOLAR getirisinde meydana gelen değişimlere yönelik varyans ayrıştırma sonuçları Tablo 11 'de yer almaktadır.

Tablo 11. LNDOLAR Varyans Ayrıştırması

\begin{tabular}{|cccccccc|}
\hline Dönem & S.E. & \multicolumn{2}{c}{ LNDOLAR LNBIST 100 } & LNFAIZ & LNEURO & LNALTIN & LNDIBS \\
\hline 1 & 1,103512 & 83,96574 & 2,977671 & 0,766750 & 12,28984 & 0,000000 & 0,000000 \\
--- & --- & --- & --- & --- & --- & -- & -- \\
11 & 1,176293 & 76,24752 & 3,102084 & 1,682082 & 14,98515 & 2,490693 & 1,492477 \\
$\mathbf{1 2}$ & $\mathbf{1 , 1 7 6 2 9 3}$ & $\mathbf{7 6 , 2 4 7 5 0}$ & $\mathbf{3 , 1 0 2 0 8 6}$ & $\mathbf{1 , 6 8 2 0 8 4}$ & $\mathbf{1 4 , 9 8 5 1 5}$ & $\mathbf{2 , 4 9 0 7 0 2}$ & $\mathbf{1 , 4 9 2 4 7 8}$ \\
13 & 1,176293 & 76,24750 & 3,102086 & 1,682084 & 14,98515 & 2,490702 & 1,492478 \\
\hline
\end{tabular}

Finansal getiri araçlarından dolar getirisi öngörü hata tahminine göre 12. dönemde dengeye gelmiştir. Tablo 11'de görüldüğü üzere dolar getirisinde meydana gelecek olan bir standart sapmalık şok \%76 oranında kendi gecikmeli değerleriyle, \%3,1'i BIST 100 endeks getirisi, \%1,6's1 faiz getirisi, \%14,98'i euro getirisi, \%2,49'u altın getirisi ve \%1,49'u DIBS getirisi ile açıklanmaktadır. Dolardaki getirilerin \%15 gibi yüksek sayılacak bir kısmı euro getirisi tarafından açıklanmaktadır. LNALTIN getirisinde meydana gelen değişimlere yönelik varyans ayrıştırma sonuçları Tablo 12'de yer almaktadır.

Tablo 12. LNALTIN Varyans Ayrıştırması

\begin{tabular}{|cccccccc|}
\hline Dönem & S.E. & LNALTIN & LNBIST 100 & LNFAIZ & LNEURO & LNDOLAR & LNDIBS \\
\hline 1 & 1,133863 & 94,45317 & 0,249038 & 0,057497 & 4,376564 & 0,863735 & 0,000000 \\
--------- & -- & -- & -- & -- & -- & -- \\
10 & 1,163273 & 91,27107 & 1,355655 & 0,883721 & 4,393282 & 1,803034 & 0,293241 \\
$\mathbf{1 1}$ & $\mathbf{1 , 1 6 3 2 7 3}$ & $\mathbf{9 1 , 2 7 1 0 6}$ & $\mathbf{1 , 3 5 5 6 5 5}$ & $\mathbf{0 , 8 8 3 7 2 2}$ & $\mathbf{4 , 3 9 3 2 8 2}$ & $\mathbf{1 , 8 0 3 0 3 6}$ & $\mathbf{0 , 2 9 3 2 4 2}$ \\
12 & 1,163273 & 91,27106 & 1,355655 & 0,883723 & 4,393284 & 1,803036 & 0,293242 \\
\hline
\end{tabular}


Finansal getiri araçlarından altın getirisi öngörü hata tahminine göre 11. dönemde dengeye gelmiştir. Tablo 12 'de görüldüğü üzere altın getirisinde meydana gelecek olan bir standart sapmalık şok \%9,27 oranında kendi gecikmeli değerleriyle, \%1,35'i BIST 100 endeks getirisi, \%0,8'i faiz getirisi, \%4,39'u euro getirisi, \%1,8'i dolar getirisi ve \%02'si DIBS getirisi ile açıklanmaktadır. Altındaki getirilerin büyük bir kısmı yine kendi değerleri ile açıklanmıştır. Altın kendi gecikmeli değeri haricinde en çok \%4,39 ile euro getirisi ile açıklanmaktadır. BIST 100 endeks getirisi, faiz getirisi ve dolar getirisi az oranda da olsa altındaki getirileri etkilemektedir. LNDIBS getirisinde meydana gelen değişimlere yönelik varyans ayrıştırma sonuçları Tablo 13'te yer almaktadır.

Tablo 13. LNDIBS Varyans Ayrıştırması

\begin{tabular}{|c|c|c|c|c|c|c|c|}
\hline Dönem & S.E. & LNDIBS & LNBIST100 & LNFAIZ & LNEURO & LNDOLAR & LNALTIN \\
\hline 1 & 0,983647 & 78,01609 & 5,290563 & 13,57539 & 2,330117 & 0,407694 & 0,380142 \\
\hline --- & --- & --- & --- & --- & --- & --- & --- \\
\hline 11 & 1,089380 & 73,83315 & 5,116206 & 13,17576 & 3,603527 & 1,925006 & 2,346352 \\
\hline 12 & 1,089380 & 73,83314 & 5,116206 & 13,17576 & 3,603533 & 1,925006 & 2,346353 \\
\hline 13 & 1,089380 & 73,83314 & 5,116205 & 13,17576 & 3,603533 & 1,925006 & 2,346354 \\
\hline
\end{tabular}

Finansal getiri araçlarından DIBS getirisi öngörü hata tahminine göre 12. dönemde dengeye gelmiştir. Tablo 13'te görüldüğü üzere DIBS getirisinde meydana gelecek olan bir standart sapmalık şok \%73,83 oranında kendi gecikmeli değerleriyle, \%5,11'i BIST 100 endeks getirisi, \%13,17'si faiz getirisi, \%3,6's1 euro getirisi, \%1,92's1 dolar getirisi ve $\% 2,34$ 'ü altın getirisi ile açıklanmaktadır. DIBS getirilerin büyük bir kısmı \%13,17 ile faiz getirisi ile açıklanmıştır. Ayrıca diğer getiri değişkenlerde az oranda olsa da DIBS getirisini açıklamaktadır BIST getirisi, diğer getiri araçlarını çok düşük düzeylerde etkilemesine rağmen, daha yüksek düzeylerde etkilenmektedir.

\section{SONUÇ VE ÖNERİ}

Türkiye'de finansal sistemden sağlanan getiri araçlarının çokluğu, bireysel ve kurumsal tasarrufların değerlendirilmesi açısından, getiri araçlarının birbirleri ile etkileşim ve nedensellik ilişkilerinin bilinmesini gerektirmektedir. Finansal getiri araçlarının istenilen karlılık düzeylerine göre seçilebilmesi ve bu getiri araçlarının minimum risk ve maksimum kazanç ölçütlerine göre getiri portföylerine dahil edilmesi için aralarında mevcut tamamlayıcılık ve ikame ilişkilerinin analiz sonuçları araştırılmalıdır. Bu açıklamaların, finansal sistemde kazanç getirici araçlara yatırım yapmak isteyen bireysel ve kurumsal tasarruf sahipleri için faydalı olması amaçlanmaktadır. Değişken sayılarının çokluğu ve veri kullanma yöntemi araştırmayı farklı kılmaktadır. Araştırmada Türkiye'de finansal sistem içinde yer alan finansal araçların getirileri olarak değerlendirilen BIST 100 endeksi, faiz, euro, dolar, altın ve DIBS arasındaki ilişkiler TÜFE bazlı reel getiri oranları baz alınarak incelenmiştir. Serilerin arasındaki ölçüm farklarını en az düzeye indirebilmek için doğal logaritmaları alınmıştır.

Değişkenler için oluşturulan korelasyon matrisinde değişkenlerin birbirleri ile ilişkilerinin düzeyi, yönü, ikame ve tamamlayıcılık durumu ayrı ayrı belirtilmiştir. Örneğin, BIST 100 endeks getirisi ile faiz getirisi arasında (ÇZİ, AY, Tİ) çok zayıf bir ilişki 
bulunmakta, ilişkinin yönü pozitif olduğundan aynı yönlü ve birbirlerini tamamlayıcılık ilişkisine sahiptirler.

Araştırmada etki-tepki analizinden elde edilen sonuçlara göre, tüm getiri değişkenlerinin kendilerinde oluşan bir standart sapmalık şoka ilk dönemde hep pozitif tepki verdikleri görülmüştür. Türkiye'de finansal sistemde sağlanan getiri araçlarından, BIST 100 endeks getirisi ile faiz, altın, dolar ve DIBS getirileri arasında hem tamamlayıcılık ve hem de ikame ilişkisi tespit edilmiştir. Cihangir vd. (2020), bu değişkenler arasında sadece ikame ilişkisi olduğunu belirtmişlerdir. İlk dönemde negatif tepki sadece altın getirisi tarafından verilmektedir. Uzun dönemde tekrar pozitif etkiye çıktığı için, altın kısa süreli değil uzun süreli yatırım aracı olarak düşünülmelidir. Faiz getirisine uygulanan şoklarda en çok altın getirisi etkilenmektedir. Euro getirisinde meydana gelen şokta ilk dönemde sadece BIST 100 endeks getirisi negatif tepki vermekte bu da aralarındaki ikame ilişkisini göstermektedir. Ayrıca DIBS, faiz ve dolar getirilerinin daha çok birbirleriyle etkileşim içinde oldukları görülmüştür.

Yatırımcılar maksimum kazanç için aralarında ikame ilişkisi bulunan getiri araçlarından portföylerine sadece bir tanesini dahil edebilirler. Aralarında tamamlayıcılık ilişkisi bulunan getiri araçlarının ise oluşturulacak portföyde birlikte yer alması kazancı maksimize edebilecektir.

Araştırmada elde edilen sonuçların; bireysel tasarruf sahipleri, kurumsal tasarruf sahipleri ve finansal sistem aktörlerine bilgi vermesi ve yol gösterici olma özelliği ile literatüre ve finansal sistem kullanıcılarına katkı sunması beklenmektedir. Son olarak da araştırmanın kısıtları hakkında şunları söyleyebiliriz. Türkiye'de finansal sistemden sağlanan getiri araçlarının etkileşimini araştırmak için BIST 100 endeksi, faiz, euro, dolar, DIBS ve altın getirileri VAR modeli esas alınarak incelenmiştir. Elde edilen sonuçlar 1şığında, modele ilave yeni getiri değişkenlerin eklenmesi, farklı bir veri seti ile birlikte uzun dönemde olabilecek yapısal kırılmalar araştırılabilir. Ayrıca yapılacak araştırmalarda seviyede durağan olmayan değişkenler kullanılarak farklı modeller ile uzun ve kısa dönem ilişkiler incelenebilir.

\section{KAYNAKLAR}

Aktaş, Hüseyin - Kayalıdere, Koray - Karataş, Yasemin (2018), "Petrol, Dolar Kuru Ve Hisse Senedi Piyasası Arasındaki Ortalama-Oynaklık Yayılım Etkisi: Bıst100 Üzerine Bir Uygulama", Muhasebe ve Vergi Uygulamaları Dergisi, Nisan Özel Sayı, ss. 354-377.

Aytekin, Sevgi - Dube, Sema (2016), "Piyasalar Arası Dinamikler: Hisse Senedi, Tahvil, Döviz ve Emtia Piyasaları Arasındaki Etkileşim ve Nedensellik İlişkileri”, Elektronik Sosyal Bilimler Dergisi, 15 (59), ss. 1311-1326.

Barut, Abdulkadir - Karaoğlan, Sadık - Karabayır, Mehmet Emin (2017), "Faiz Oranı-Döviz Kuru ve Bist100 Etkileşimi: Makı Eş-Bütünleşme Analizi", Kafkas Üniversitesi İktisadi ve İdari Bilimler Fakültesi Dergisi, 8(16), ss. 503-523. 
Cihangir, Mehmet - Polat, Mehmet A. - Çalışkan, Uğraş (2020), “Türkiye'de Alternatif Finansal Yatırım Araçları Arasındaki Dinamik Etkileşim: Uygulamalı Bir Analiz", Journal of Yaşar University, 15(60), ss. 920-940.

Cingöz, Fatih - Kendirli, Selçuk (2019), “Altın Fiyatları, Döviz Kuru ve Borsa İstanbul Arasındaki İlişki”, Finans Ekonomi ve Sosyal Araştırmalar Dergisi, 4 (4), ss. 545-554.

Çiçek, Macide (2010), "Türkiye'de Faiz, Döviz ve Borsa: Fiyat ve Oynaklık Yayılma Etkileri”, Ankara Üniversitesi SBF Dergisi, 62(2), ss. 1-28.

Demirkale, Özge - Ebghaei, Felor (2020), "Ham Petrol Fiyatları ile Makroekonomik ve Finansal Göstergeler Arasındaki Karşılıklı İlişkinin VAR Modeli ile Analizi: Türkiye Üzerine Bir Uygulama", Finans Ekonomi ve Sosyal Araştırmalar Dergisi, 5(4), ss. 688-698.

Dickey, David A. - Fuller, Wayne, A. (1979), "Distribution of the Estimators for Autoregressive Time Series with a Unit Root”, Journal of American Statistical Association, 74, pp. 427-431.

Dickey, David A. - Fuller, Wayne, A. (1981), "Likelihood Ratio Statistics for Autoregressive Time Series with a Unit Root”, Econometrica (49), pp. 1057-1072.

Doğru, Bülent - Recepoğlu, Murşit (2014), “Türkiye'de Hisse Senedi Fiyatları ve Döviz Kuru Arasında Doğrusal ve Doğrusal Olmayan Eş Bütünleşme İlişkisi”, Dumlupınar Üniversitesi Sosyal Bilimler Dergisi, XIV. Uluslararası Ekonometri Yöneylem Araştırması ve İstatistik Sempozyumu Özel Sayısı, ss. 17-34.

Durmuş, Savaş - Yılmaz, Tuncer - Şahin, Dilek (2019), "Makro Ekonomik Göstergelerin Endeks Getirileri Üzerindeki Etkisi: BIST Örneği”, Avrasya Uluslararası Araştırmalar Dergisi, 7 (16), ss. 870-886.

Elmastaş Gültekin, Özge - Aktürk Hayat, Elvan (2016), “Altın Fiyatını Etkileyen Faktörlerin Var Modeli ile Analizi: 2005-2015 Dönemi”, Ege Academic Review, 16(4), ss. 611625.

Gunasekarage, Abeyratna - Pisedtasalasai, Anirut - Power, David M. (2004), "Macroeconomic Influence on the Stock Market: Evidence from an Emerging Market in South Asia”, Journal of Emerging Market Finance, 3(3), pp. 285-304.

Güler, Sevinç - Özçalık, Melih (2018), "Hisse Getirisi, Faiz Oranı ve Dolar Kuru İlişkisi”, Manisa Celal Bayar Üniversitesi Sosyal Bilimler Dergisi, 16 (4), ss. 291-306.

Hatemi, Abdulnasser J. - Irandoust, Manuchehr (2002), “On the Causality between Exchange Rates and Stock Prices: A Note”, Bulletin of Economic Research, 54(2), pp. 197-203.

Joseph, Nathan L. (2002), "Modelling The Impacts Of Interest Rate and Exchange Rate Changes on UK Stock Returns”, Derivatives Use, Trading and Regulation, 7(4), pp. 306-323. 
Karan, Mehmet Baha (2018), Yatırım Analizi ve Portföy Yönetimi, 5. Baskı, Gazi Kitabevi, Ankara.

Kayahan, Leman - Hepaktan, Erdem (2016), “Türkiye'de Elektronik Ticaret Hacmini Etkileyen Faktörlere İlişkin Var Analizi (2005-2015)", Ardahan Üniversitesi İİBF Dergisi, 2 (4), ss. 159-190.

Koyuncu, Tuğba - Meçik, Oytun (2020), “Covid-19 Pandemisinin Türkiye’de Ekonomik Büyümeye Sektör-Spesifik Etkileri: VAR Analizi”, Yönetim ve Ekonomi Araştırmaları Dergisi, 18 (4), ss. 112-131.

Markowitz, Harry (1952), “Portfolio Selection”, Journal of Finance, 7(1), pp. 77 - 91.

Mucuk, Mehmet - Alptekin Volkan (2008), “Türkiye'de Vergi ve Ekonomik Büyüme İlişkisi: VAR Analizi (1975-2006)”, Maliye Dergisi, 155(2), ss. 159-174.

Öz, Ferdi - Polat, Müslüm - Boydak, Hikmet Ubeyd (2020), “Ekonomik Büyümenin Borsa Temelli Finansal Gelişmeye Etkisi, Bucak İşletme Fakültesi Dergisi”, 3 (2), ss. 159175.

Phillips, Peter C.B. - Perron, Pierre (1988), “Testing for a Unit Root in Time Series Regressions”, Biometrica, 75, pp. 335- 346.

Saka Ilgın, Kübra - Sarı, Sercan S. (2020), "Döviz Kuru, Faiz Oranı ve Enflasyon ile BIST Tüm ve BIST Sektörel Endeksler Arasındaki İlişkinin Ampirik Analizi”, Ekonomi Politika ve Finans Araştırmaları Dergisi, 5 (3), ss. 485-510.

Sever, Erşan - Demir, Murat (2007), "Türkiye'de Bütçe Açığı ile Cari Açık Arasındaki İlişkilerin VAR Analizi ile İncelenmesi”, Eskişehir Osman Gazi Üniversitesi İktisadi ve İdari Bilimler Fakültesi Dergisi, 2 (1), ss. 47-64.

Sims, Christopher A. (1980), “Macroeconomics and Reality”, Econometrica, 48(1), pp. 1-48.

Sui, Lu - Sun, Lijuan (2016), "Spillover Effects Between Exchange Rates and Stock Prices: Evidence From BRICS Around the Recent Global Financial Crisis”, Research in International Business and Finance, 36, pp. 459-471.

Tangjitprom, Nopphon (2012),"Macroeconomic Factors of Emerging Stock Market: The Evidence from Thailand”, SSRN Electronic Journal, pp. 105-114.

Tar1, Recep - Bozkurt, Hilal (2011), “Türkiye’de İstikrarsız Büyümenin VAR Modelleri ile Analizi (1991.1-2004.3).” Istanbul University Econometrics and Statistics e-Journal, $0(4)$, ss. 1-16.

Topcu, Nuraydın - Aksoy, Mine - Topcu, Nuraydın (2013), "Altın ile Hisse Senedi ve Enflasyon Arasındaki İlişki”, Atatürk Üniversitesi İktisadi ve İdari Bilimler Dergisi, 27(1), ss. 59-78. 
Yaghi, Mostafa K. (2020), "Causality between Inflation Rate and Stock Prices Index (Evidence from Damascus Securities Exchange)”, Tishreen University Journal for Research and Scientific Studies, 42(1), pp.717-731.

Yıldırım, Selim - Ögel, Serdar - Alhajrabee, Omar (2020), “Enflasyon ve Faiz Oranlarının Hisse Senedi Getirilerine Etkisinin Araştırılması: BIST Mali Endeksi Üzerinde Ampirik Uygulama”, Balkan Sosyal Bilimler Dergisi, 9 (17), ss. 185-191.

Yıldız, Ayşe (2014), "BIST 100 Endeksi ile Alternatif Yatırım Araçlarının İlişkisi”, Süleyman Demirel Üniversitesi İktisadi ve İdari Bilimler Fakültesi Dergisi, 19(2), ss. 39-56.

Yiğiter, Yüksel Ş. - Akkaynak, Bilal (2017), "Modern Portföy Teorisi: Alternatif Yatırım Araçları ile Bir Uygulama”, Kahramanmaraş Sütçü İmam Üniversitesi Sosyal Bilimler Dergisi, 14 (2), ss. 285-300. 
